Int. J. Curr. Res. Med. Sci. (2017). 3(4): 80-86

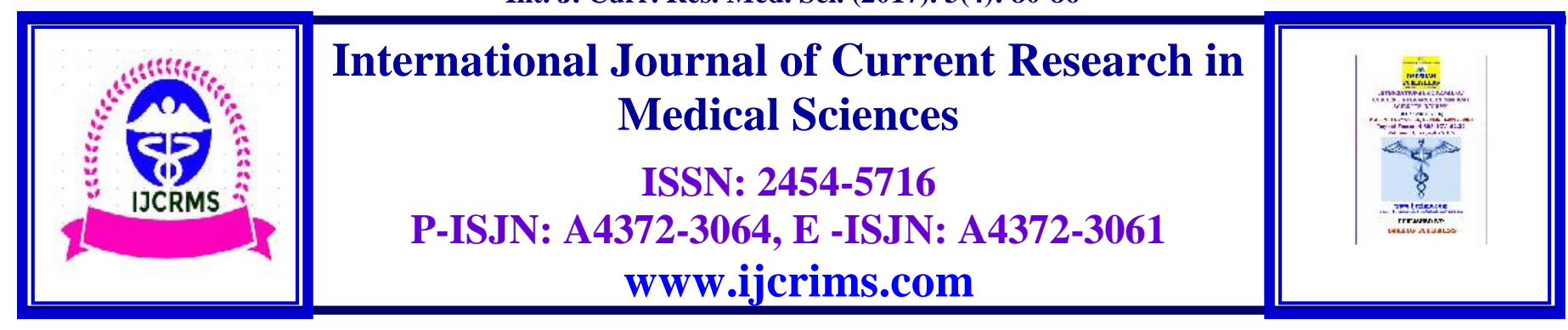

Review Article

Volume 3, Issue 4 -2017

DOI: http://dx.doi.org/10.22192/ijcrms.2017.03.04.013

\title{
Notional study on Nadi paritchai - A review
}

\author{
S. Mohamed Ajmal ${ }^{1}$, Uma A.P \\ ${ }^{1}$ Department of Kuzhandhai maruthuvam \\ ${ }^{2}$ Lecturer, Department of Kuzhandhai maruthuvam, Sivaraj Siddha Medical College, Salem-636307. \\ *Corresponding author: mohamedajmal955@gmail.com
}

\begin{abstract}
The term pulse is inadequate to represent the rich conception and the complex range of perceptions and observations which the Siddhars had meant in the term Nadi. The main aim of the study was to make a literary overview of Nadi paritchai as described in Siddha. Its diagnostic applicability in modern science creates strong belief regarding old concepts and their authenticity comparing it with modern school of thoughts. This examination has been recognized as one of the principal means of diagnosis and prognosis of diseases in this ancient land from the time immemorial.
\end{abstract}

Keywords: Nadi paritchai, Siddha, Modern science.

\section{Introduction}

In Siddha medicine, pulse diagnosis is called Nadi paritchai which is very important diagnostic method in Envagai thervu. Pulse diagnosis is a quick, inexpensive and non invasive beside diagnostic tool. Nadi Paritchai can be understood by the vibrations carried out by the blood which circulates to every part of the body. The different diseases could readily be diagnosed with the aid of the pulse. In this given review work focused the diagnosis of diseases based on examination methods of Nadi paritchai and also to go through the various literatures regarding the relevant topic.

\section{Method of Nadi paritchai ${ }^{1}$}

Patient and physician should sit comfortably facing each other, preferably at the same height; it is advisable to examine the pulse of the patient in sitting position. The physician should sit on the right side of the patient and hold the right hand of male or left hand of female at wrist with his right hand while supporting the arm of the patient at the elbow with his left hand. The physician should keep three fingers i.e. index, middle and ring of his right hand on the radial pulse just adjacent to the "styloid" process situated just 1 finger below the root of thumb. The position of the fingers should be such that index finger lies adjacent to the styloid process. The physician should examine the pulse by applying gentle and equal pressure of his three fingers on the pulse.

\section{Common sites for examination of $\mathrm{Nadi}^{2,3}$}

1. Kuthi santhu (Popliteal artery)

2. Kaamiyam (Femoral artery)

3. Unthi (Epigastric region) 
4. Maarbu (Cardiac region)

5. Kaadhu (Posterior Auricular Branch of External Carotid Artery)

6. Mooku (Ophthalmic artery)

7. Kandam (Common Carotid artery)

8. Karam (Radial artery)

9. Puruvam (Superficial Temporal artery)

10. Utchi (Top of the skull)

\section{Time of nadi examination ${ }^{4}$}

The pulse should be examined in the morning on empty stomach in a calm and peaceful atmosphere, but can be examined at any time in an emergency. Even a day is divided into three phases or parts and each part is said to be a prominent phase of Vaatham is morning 6$10.00 \mathrm{am}$ and evening $6-10.00 \mathrm{pm}$, Pitham is morning $10.00 \mathrm{am}$ to $2.00 \mathrm{pm}$ and night at $10.00 \mathrm{pm}$ to $2.00 \mathrm{am}$ and Kapham during early morning at 2-6.00am and 2-6.00pm.

\section{Practical demonstration of pulse}

The easy way to understanding these concepts, the three main divisions are made for the movement of the pulse, which illustrates the gait of various animals, birds and reptiles. In Vaatham - the pulse movement is compared to the gait of serpent or leech. In Pitham - like the gait of sparrow, crow or frog. In Kapham - the gait of swan, elephant or pigeon. These may be present in any combination and should be understood accordingly ${ }^{1,5}$.

The increased Vaatham feature represents muscle wasting, blackish coloration, tremors, distended abdomen, constipation, weakness, insomnia and lack of inspiration. If in decreased Vaatham features like body pain, feeble voice, diminished capability of brain and syncope. Look like in increased Pitham features expressed are increased thirst and appetite, burning sensation, increased sweat, decreased sleep and yellowish discoloration of the conjunctiva, feces, urine and skin. Simultaneously, the decreased Pitham features like loss of appetite and reduced surface temperature, pallor. Predominance of Kapham cause cold, shivering, loss of appetite, pain in the upper chest, asthma, bronchitis, blood vomiting, sweet taste in mouth and tongue ${ }^{2}$. The considerations of parameters for Nadi are listed below (table 1).

Table 1. The consideration of parameters for Nadi examination

\begin{tabular}{|c|c|c|c|}
\hline Parameters & Vaatham & Pitham & Kapham \\
\hline Location & Index finger & Middle finger & Ring finger \\
\hline Speed & Rapid & Medium fast & Slow / Steady \\
\hline Rhythm & Irregular & Regular & Regular \\
\hline Force & Low + & High +++ & Moderate ++ \\
\hline Volume & Low & High & Moderate \\
\hline Temperature & Cold & Hot & Warm to cool \\
\hline Vessel wall & Rough, hard & Elastic, flexible & Soft thickening \\
\hline Characteristics & $\begin{array}{l}\text { Fast, feeble, cold, light, } \\
\text { thin, disappears on } \\
\text { pressure }\end{array}$ & $\begin{array}{l}\text { Prominent, strong, high } \\
\text { amplitude, hot, forceful, } \\
\text { lifts palpating finger }\end{array}$ & $\begin{array}{l}\text { deep, slow, broad, } \\
\text { wavy, thick, cool or } \\
\text { warm, regular }\end{array}$ \\
\hline
\end{tabular}

\section{Nadi in different condition of Body \& $\operatorname{Mind}^{6}$}

1. Happy person: Pulse is steady

2. Hungry Persons: Pulse is tremulous

3. In anxious, fear, sorrow and disgust: Pulse is weak
4. In Fever: Pulse becomes fast and is felt hot to touch

5. In Psychological conditions like anger and excitement: Pulse becomes fast.

6. Digestion: In the state of poor digestive power, the pulse becomes very slow and 
low in volume, in good digestive power, the pulse is felt light and fast.

7. In satiety: the pulse is consistent.

8. During Sexual urge: Pulse is fast

9. In Dhatu depletion (diminished tissues): Pulse becomes very slow and low in volume.

\section{Levels of the Pulse ${ }^{7}$}

1. The deepest level of the pulse is the Prakriti $\left(1^{\text {st }}\right)$,

2. Then up from there Manas Prakriti $\left(2^{\text {nd }}\right)$,

3. Sub thodam $\left(3^{\text {rd }}\right)$,

4. Kapham (Ojas)/Pitham (Tejas)/Vaatham (Pranan) $\left(4^{\text {th }}\right)$,

5. Dhatus $\left(5^{\text {th }}\right)$,

6. Manas Vikriti $\left(6^{\text {th }}\right)$,

7. Vikriti $\left(7^{\text {th }}\right)$.

In each level many sensations can be experienced and eventually understood by the advanced practitioner. We must remember that feeling initially takes place in the mind and then in the fingers. It is our mind's eye that truly reads the pulse and not the fingers alone. At each level of the pulse there is a minor variation in the spike of the pulse. As one continually moves from deep to superficial pulses they begin to differentiate between the many levels of the pulse.

\section{$1^{\text {st }}$ and $7^{\text {th }}$ Level Organ Pulses ${ }^{8}$}

The organ pulses can be felt in both the Prakriti and Vikriti levels. The first level corresponding to Prakriti is associated with the superficial organs. The seventh level corresponds to Vikriti is associated with the denser organs deeper within the abdomen. Organ pulses are taken on both the right and left hand of the recipient (table $2 \& 3$ ). These link the finger, Thodam, level and organs together.

Table 2 Organ pulses on Right side

\begin{tabular}{|c|c|c|c|}
\hline Thodam (Dosha) & Vaatham & Pitham & Kapham \\
\hline Finger & Index & Middle & Ring \\
\hline Superficial & Large intestine & Stomach & Triple warmer \\
\hline Deep & Lung & Spleen & Pericardium \\
\hline
\end{tabular}

Table 3 Organ pulses on Left side

\begin{tabular}{|c|c|c|c|}
\hline Thodam (Dosha) & Vaatham & Pitham & Kapham \\
\hline Finger & Index & Middle & Ring \\
\hline Superficial & Small intestine & Gall bladder & Bladder \\
\hline Deep & Heart & Liver & Kidney \\
\hline
\end{tabular}

\section{$3^{\text {rd }}$ Level Subthodam ${ }^{7}$}

The third levels down are the Subthodam pulses, the tip of the pulse feeling finger tips into 5 segments. On Vaatham finger beginning from the most distal point from the heart the Vayus or winds go in order from Pranan, Udanan, Vyanan, Samanan, Apanan. On the Pitham finger from thumb to heart is Prachaka pitham, Ranjaka pitham, Anala pitham, Alochaka pitham, Sadhaka pitham. On the Kapham finger moving towards the heart is Kledakam, Avalambakam, Sandekam,
Bodhakam, Tarpakam. Spikes on one of these places on the finger indicate an imbalance in that Subthodam. The Subthodam actions and functions are always the same.

\section{$4^{\text {th }}$ Level Subtle energies ${ }^{7}$}

Kapham (Ojas), Pitham (Tejas) and Vaatham (Pranan) are the subtle energetic parts. Kapham (Ojas) can be felt in the ring finger, Pitham (Tejas) is felt in the middle finger and Vaatham (Prana) in the index finger. 
Vaatham (Prana) Pitham (Tejas) and Kapham (Ojas) relate to the body in many ways even though they are the subtle counterparts of the Thodam. In the endocrine system, Vaatham (Prana) is related to equilibrium and adaptability to different situations. It is also found in the pituitary and pineal gland. Pitham (Tejas) is responsible for the digestion and metabolism of the thyroid gland and pancreas. Kapham (Ojas) deals with reproduction, the most unrefined of endocrine secretions, since the endocrine fluid is created from the reproductive fluid. Kapham (Ojas) also governs energy reserves and is found in the testes, ovaries and adrenals. The subtle energies influence the physical body. Vaatham (Pranan), Pitham (Tejas) and Kapham (Ojas) are the primary energizing principles of the body as expressed by the immune system. The immune system is a collaboration of all the systems for maintaining health and neutralizing disease. The pulse as expressed through the chemical and physical actions of the blood is mirrored in the subtle energies. Vaatham (Pranan) is the underlying movement that defines where the immune response will be most prevalent. Pitham (Tejas) is the active, fiery element that mobilizes the tools of the immune system. Kapham (Ojas) is the innate capacity of the system, its tool box and energy supply for coming back into balance. On the fourth level of the pulse these qualities can be determined. We can detect these differences is subjective. Listen to the amplitude of the highest point of the pulse's crest, its spike, in each finger. Give the strength of the spike a number.

\section{$5^{\text {th }}$ Level Dhatus (Tissues) ${ }^{7}$}

At the fifth level of the pulse we can assess the strength and quality of the tissues. The seven tissues are Rasa (Plasma and Fluid), Raktam (Blood), Oon (Muscle), Kozhupu (Fat), Enbu (Bone), Moolai (Marrow) and Sukkilam/Suronitham (Reproductive Tissue male and female). Healthy Dhatus will not spike, it is when the Dhatus have been invaded by excess thodam (Doshas) or are weak that a spike will be felt. The quality of the spike is very important. If it is sharp and intense then there is Pitham in that tissue. If it is dull and solid then Kapham and if it is feeble and thread-like then Vaatham is present.
The male and female reproductive tissues are found at the center point of the finger tip on every finger when a spike is detected. Because the reproductive tissue is felt on all three center parts of the fingers it is not only the quality of the spike, but whether the finger is Vaatham, Pitham, or Kapham that determines the imbalance. When a spike is felt on the ring finger in the proximal position (close to the heart) the Rasam is compromised, on the distal position kurudhi. On the middle finger proximal is Oon and distal is kozhupu. On the index finger proximal relates to enbu and distal to Moolai.

\section{Second and Sixth Level Manas Prakriti (Flow of Consciousness) ${ }^{7}$}

The second and sixth levels of the pulse are finely tuned to the mind. It is here that we discover our mental imbalance or balance and identify the deeper flow of consciousness as defined by chakras. It is here in the mind that objective reality is converted into subjective reality through our senses and perceptions. These levels are the bridge between body and mind, objective and subjective. As the majority of this technique is subtle and quite different than the previous techniques the aspects that relate most directly to the other levels of the pulse will only be described. These levels of the pulse take a sensitive awareness and cannot adequately be described in a technical way. Again the tips of the fingers are divided into thirds. In this level Vaatham Pitham Kapham can be felt in all three fingers. The third of the finger closest to the heart relates to Kapham, the third in the center to Pitham and the third towards the thumb to Vaatham. Vaatham felt on the distal edge of each finger, Pitham in the middle and Kapham proximal to the midline of the recipient. Each of these Doshas is influenced by a Gunam (quality of the mind) this is how the characteristics of the Dosha will manifest in the mind.

In the second level of the pulse the qualities of the mind are Sattuva gunam, Rajo gunam and Tamo gunam. Sattva gunam is the underlying energy of peace and truth. Sattuva gunam has an inward and upward movement bringing us towards our true nature. It is the true state of consciousness: light, 
stable, harmonic, and virtuous. Rajas are the qualities of passion, turbulence, activity, distraction, assertion, motivation and movement. Its action is outward, egoistic, self-seeking and self-motivated. Tamo gunam is cloudy, dull, sticky, cold and stagnant. It is the inertia of downward motion causing decay, degeneration and death. The second level pulse is connected moment to moment to our minds eye.

The sixth level of the pulse relates to the seven Chakras. The seven Chakras are the energy centers of the subtle body. There are many of them, but the pulse identifies the seven that lie along the spine. They show how the life force directs and guides the physical body through the nervous system. The crown center Chakram can be felt as a spike at the center part of all the pulse taking fingers if it is blocked. On the ring finger the root Chakram is felt in the distal position (close to the thumb, far from the heart) and the navel Chakram is felt on a proximal position. On the middle finger a spike on the edge closest to the thumb is the will Chakram and towards the heart is the heart Chakram. The Index finger can feel the throat Chakram on its distal edge and the third eye Chakra on its proximal edge. Manas Prakriti does not change unless the Chakras are open and one becomes enlightened. A spike indicates an imbalance or blockage in these subtle energy centers (table 4).

Table 4. The chakras are related to the elements and organs for further clarification of their physical manifestation?

\begin{tabular}{|c|c|c|c|}
\hline CHAKRA & ELEMENTS & SENSE ORGANS & ACTION ORGANS \\
\hline Mooladharam- root & Earth & Nose- smell & Anus \\
\hline Suvathitanam- navel & Water & Tongue-taste & Reproductive organs \\
\hline Manipooragam- will & Fire & Eye-sight & Feet \\
\hline Anagatham- heart & Air & Skin-touch & Hands \\
\hline Visuthi- throat & Ether & Ears-sound & Mouth \\
\hline Aakinai- third eye & Mind & Mind & Mind \\
\hline Sahasradharam- crown & Spirit & $\begin{array}{c}\text { Virtual nervous } \\
\text { system }\end{array}$ & Virtual nervous system \\
\hline
\end{tabular}

\section{Modern concept}

\section{(A) Pulse}

Pulse represents the tactile arterial palpation of the heartbeat by trained fingertips. The pulse may be palpated in any place that allows an artery to be compressed against a bone ${ }^{2}$.

\section{(B) Physiology of pulsation}

Pulse is a pressure wave that travels along the vessel wall. The factors responsible for the pulse are the intermittent flow of blood from the heart i.e the stoke volume output, the resistance to outflow of blood from the arterioles into the capillaries and the elasticity of the arterial walls $^{2,5}$.

\section{(C) Mechanism of pulse formation}

For clinical examination of the pulse the radial artery is selected as it is easily accessible and remains against the bone which works as hard bed when the pressure is used at the time of examination. It is recognized due to its position in the side of the thumb. Distensibility of the vessels is controlled by their content of elastic and collagen tissues and smooth muscles. Systolic ejection distends aorta and its large branches, subsequent to the closer of the aortic valve to the termination of the systole of left ventricle of the heart. When we examine pulse (at radial artery) we feel a wave type movement commencing in a series. Pulse can be described as the expansion and elongation of arterial walls passively produced by the pressure changes during systole and diastole of the ventricles. 
Fundamentally, the pumping action of the heart generates blood flow. Pressure results when the flow is opposed by resistance. By the examination of pulse, various physiological and pathological stages of the heart can be observed ${ }^{5}$.

(D) Examination of pulse and its indications $^{2}$

While examing the pulse the physician will naturally look into the following factors:
1. Rate

2. Rhythm

3. Volume

4. Force

5. Character

6. Condition of arterial wall

7. Temperature of skin over the pulse

1. Rate

This denotes the number of beats or waves felt per minute $^{10}$ (table 5)

Table 5 Normal pulse rates at rest, in beats per minute (BPM)

\begin{tabular}{|c|c|c|c|c|c|}
\hline $\begin{array}{c}\text { Newborn (0-3 } \\
\text { months old) }\end{array}$ & $\begin{array}{c}\text { Infants } \\
\mathbf{( 3 - 6} \\
\text { months) }\end{array}$ & $\begin{array}{c}\text { Infants } \\
\mathbf{( 6 - 1 2} \\
\text { months) }\end{array}$ & $\begin{array}{c}\text { Children } \\
\mathbf{( 1 - 1 0} \\
\text { years) }\end{array}$ & $\begin{array}{c}\text { Children } \\
\text { over 10 years\& adults, } \\
\text { Including seniors }\end{array}$ & $\begin{array}{c}\text { Children } \\
\text { over 10 years\& } \\
\text { adults, including } \\
\text { seniors }\end{array}$ \\
\hline $100-150$ & $90-120$ & $80-120$ & $70-130$ & $60-100$ & $40-60$ \\
\hline
\end{tabular}

\section{Rhythm}

A normal pulse is regular in rhythm and force. It indicates whether the beats are equidistant or not. Two types of rhythms are regularly irregular and irregularly irregular.

\section{Volume}

This indicates the amount of distension of the arterial walls felt during the movement of a pulse wave. This is recognized by the rise and fall of the tracing fingers according to the rise and fall of the arterial wall.

\section{Force}

It is the approximate measure of the systolic pressure.

\section{Character}

The nature of the pulse wave i.e the rise, summit fall of the particular wave is recognized as character

\section{Condition of the Arterial wall}

The thickness of the wall is estimated by rolling the artery on the underlying bone of the wrist. In young age, arteries are soft difficult to palpable, in old age, arteries are easily palpable.

\section{Temperature of the skin}

The temperature over the part where the pulse is being examined is also felt with association of clinical examination of the pulse ${ }^{5}$ (table 6)

Table 6 Pulses in Various Diseases

\begin{tabular}{|l|l|}
\hline Alcoholism & Full pulse \\
\hline Anxiety & Feeble and Low Tension Pulse \\
\hline Bacillary Dysentery & Rapid and Small \\
\hline Angina Pectoris & High tension Pulse \\
\hline Pneumonia & Rapid pulse \\
\hline Myxodema & Slow Pulse \\
\hline Tuberculosis & Rapid and Feeble Pulse \\
\hline Typhoid Fever & Slow Pulse \\
\hline
\end{tabular}




\section{Discussion}

The result of examination of the pulse is predicted in terms Tiri thodam and only with status of derangements of this Tiri thodam diagnosis of the diseases is to be done by this method not only the diseases is diagnosed but also the etiology or root cause of that diseases is also found out. These forms a good line of treatment which only cures the diseases but also rectify the cause and aid for the restoration of life.

\section{Conclusion}

The intensity of Nadi forms as the vital force of life of the organism as a whole, manifesting the equilibrium of Tiri thodam, by maintaining the gaseous exchange balance, thermal balance, fluid or water balance and consequently promotes the progress of health for restoration of life.

\section{References}

1. Dr.Shanmugavel, Noi naadal part noi mudhal naadal thiratu, $6^{\text {th }}$ edition 2014, p.no. 135 .

2. Dr.S.Chidambarathanu pillai, Siddha system of pulse reading, $1^{\text {st }}$ edition 1993 p.no 71, 83, $85,90,91 \& 145$.

3. Dr.A.S.Moni, Fundamentals of human anatomy vol 3, $2^{\text {nd }}$ edition, 2002, p.no.214.

4. Dr.Thirunarayanan, Introduction to siddha medicine, $1^{\text {st }}$ edition 2016, p.no. 84.

5. Dr Gupta Vikas ${ }^{1}$, DR Sodhi Danisha ${ }^{2}$, DR Gupta $\mathrm{Nidhi}^{3}$, Conceptual Study On Nadi Vigyana, Volume 3, issue 2, 2016, page no. 1547-1552. e-ISSN: 2348-991X p-ISSN: 2454-9576.

6. S.Veeraperumal pillai, Nam naatu vaithiyam, $1^{\text {st }}$ edition, 2007, p.no. 33-34.

7. Naram, Smita, Ayushakti slide presentation, 2000, Ayushakti. vol 2005.

8. Dr.Saravanan, Nadi parisodanai ivvalavudhan, $1^{\text {st }}$ edition, 2011, p.no. 12-13.

9. Dr. Mishra Swami Nath, NADIGYANA TARANGINI Edition 2007.

10. Dr.S.Subbaiya pandian, Siddha vaithiya kalangiyam, $1^{\text {st }}$ edition, 2018, p.no. 58 .

\begin{tabular}{|c|l|}
\hline \multicolumn{2}{|c|}{ Access this Article in Online } \\
\hline \multicolumn{1}{|c|}{} & Website: \\
\hline & www.ijcrims.com \\
\hline Quick & Subject: \\
\hline & Siddha Medicine \\
\hline
\end{tabular}

How to cite this article:

S. Mohamed Ajmal, Uma A.P. (2017). Notional study on Nadi paritchai - A review. Int. J. Curr. Res. Med. Sci. 3(4): 80-86.

DOI: http://dx.doi.org/10.22192/ijcrms.2017.03.04.013 